\title{
Aplikasi Macromedia flash untuk Meningkatkan Pemahaman Konsep Matematika Siswa
}

\author{
Nia Kania ${ }^{1 *}$, Zaenal Arifin ${ }^{2}$ \\ 1,2Program Studi Pendidikan Matematika, Universitas Majalengka, Majalengka, Indonesia; \\ 1*niakania@unma.ac.id
}

Info Artikel: Dikirim: 3 Desember 2019 ; Direvisi: 11 Februari 2020; Diterima: 11 Maret 2020 Cara sitasi: Kania, N, \& Arifin, Z. (2020). Aplikasi Macromedia flash untuk Meningkatkan Pemahaman Konsep Matematika Siswa. JNPM (Jurnal Nasional Pendidikan Matematika) 4(1), 96-109.

\begin{abstract}
Abstrak. Penelitian ini berfokus pada peningkatan kemampuan pemahaman konsep siswa dalam pembelajaran matematika. Pendekatan pembelajaran yang efektif yang digunakan dengan memanfaatkan media teknologi informasi dalam bentuk pembelajaran digital adalah aplikasi macromedia flash. Macromedia flash dapat membantu menjelaskan konsep matematika yang kepada siswa dengan tampilan yang menarik. Tujuan penelitian ini adalah untuk menganalisis; (1) kemampuan pemahaman konsep matematika siswa yang menggunakan macromedia flash; (2) respons siswa terhadap penggunaan macromedia flash dalam pembelajaran. Penelitian ini merupakan kuasi eksperimen dengan desain kelompok pretes-postes menggunakan macromedia flash dalam pembelajaran matematika. Populasi dalam penelitian ini adalah seluruh siswa kelas IX SMP Negeri di Majalengka. Instrumen penelitian berupa tes kemampuan pemahaman konsep matematika dan angket. Analisis data menggunakan Paired t-test. Penelitian menghasilkan: (1) peningkatan kemampuan pemahaman konsep matematika siswa dengan kategori sedang, dan (2) respon positif siswa terhadap penggunaan macromedia flash diatas skor netralnya.
\end{abstract}

Kata Kunci: Aplikasi Macromedia flash, Geometri, Pemahaman Matematis, Pemahaman Konsep Matematika.

Abstract. This research focused on increasing student conceptual understanding in learning mathematics. An effective learning approach that was used by utilizing information technology media in the form of digital learning was the Macromedia flash Software. Macromedia flash could help explain mathematical concepts to students with an attractive appearance. The purpose of this study was to analyze; (1) student conceptual understanding whose used Macromedia flash; (2) students' responses to the use of Macromedia flash in learning. This research was a quasi-experimental design with a pretestposttest group using Macromedia flash in learning. The population in this study was all $9^{\text {th }}$ grade students at Junior High School in Majalengka. The research instrument was a test of students' mathematical understanding and questionnaires. Data analysis used a paired ttest. The research results were: (1) there was an increase in student mathematics conceptual 
understanding in the medium category, and (2) students had positive responses to the use of Macromedia flash above their neutral scores.

Keywords: Macromedia Flash Software, Geometry, Mathematical Understanding, Understanding Mathematics Concepts.

\section{Pendahuluan}

Pada masa sekarang, pembelajaran terintegrasi pada perkembangan teknologi. Perkembangan teknologi banyak memberikan keuntungan dalam meningkatkan kualitas pembelajaran. Matematika mendasari perkembangan teknologi modern pada era revolusi industri 4.0. Costley (2014) menyatakan bahwa teknologi memberikan pengalaman belajar yang bermakna. Lebih lanjut Abidin, Mulyono, \& Saputro (ㅁ13) menjelaskan bahwa matematika adalah salah satu ilmu dasar, baik aspek terapannya maupun aspek penalarannya mempunyai peranan yang penting dalam upaya penguasaan ilmu dan teknologi. Istikomah (2019) perkembangan TIK sekarang membawa banyak manfaat, terutama dalam pembelajaran matematika. Adamides \& Nicolaou (2004) pengajar matematika memiliki sikap yang sangat positif terhadap teknologi dan dalam beberapa kasus bahkan lebih positif daripada siswa.

Salah satu tujuan dari pembelajaran matematika adalah menanamkan konsep kepada siswa secara baik dan melekat. Pemahaman konsep matematika adalah dasar untuk dapat memecahkan masalah matematika maupun masalah dalam keseharian siswa. Kemampuan pemahaman konsep matematika yang baik dapat membangun kemampuan matematika lainnya yang lebih kompleks. Kent \& Foster (2016) pemahaman konseptual dipandang sebagai lebih penting, otentik dan memuaskan bagi pelajar, mewakili akal matematika yang sebenarnya. Ningsih \& Paradesa (2018) tujuan pertama belajar matematika adalah siswa memiliki kemampuan untuk memahami konsep matematika. Lebih lanjut, Setyaningrum (2018) pemahaman konseptual dalam matematika mengacu pada pengetahuan tentang fakta dan aplikasi dari konsep matematika.

Polya (1973) menyatakan empat tingkatan kemampuan pemahaman konsep matematika sebagai berikut: (1) Mekanika, jika siswa dapat mengingat dan menerapkan konsep dengan benar; (2) Induktif, jika siswa menerapkan konsep pada sebuah kasus yang sederhana dan meyakini bahwa konsep berlaku dalam kasus serupa; (3) Rasional, jika siswa bisa membuktikan kebenaran dari sebuah konsep; dan (4) Intuitif, jika siswa yakin akan kebenaran konsep tanpa ragu-ragu. Sementara itu Skemp \& Prologue (2005), membedakan dua jenis pemahaman yaitu; (1) Pemahaman Instrumental, jika 
siswa hanya menghafal rumus dan menerapkannya tanpa mengetahui alasan dan penjelasannya (2) Pemahaman Relasional, jika siswa memahami struktur dari sebuah konsep secara bermakna.

Ningsih (2013) menyatakan bahwa masalah utama yang sering dihadapi pada pelajaran matematika adalah rendahnya kemampuan pemahaman konsep siswa. Hal ini juga dialami oleh siswa SMPN 3 Majalengka. Berdasarkan hasil observasi pendahuluan, masih banyak siswa yang tahu rumus tapi tidak memahami konsepnya. Diduga penyebab rendahnya kemampuan pemahaman konsep matematika siswa yaitu pembelajaran yang menekankan pada latihan soal serta menggunakan rumus. Selain itu, pokok bahasan Bangun Ruang Sisi Lengkung merupakan materi yang membutuhkan visualisasi tinggi. Seringkali siswa kesulitan ketika harus memvisualisasikan sebuah selimut pada bangun ruang sisi lengkung. Rendahnya pemahaman konsep matematika siswa berdampak pada proses pembelajaran sehingga siswa kesulitan menyelesaikan permasalahan matematika. Salah satu solusi yang dapat meningkatkan pemahaman konsep matematika siswa adalah penggunaan macromedia flash (Herbst, Chieu, \& Rougee, 2014; Moradmand, Datta, \& Oakley, 2014)

Macromedia flash merupakan software yang menampilkan animasi sederhana untuk menjelaskan konsep matematika. Penggunaan macromedia flash dapat memvisualisasikan konsep matematika yang abstrak menjadi kongkrit, meningkatkan perhatian siswa pada pembelajaran dan memungkinkan pengulangan berulang (retensi) bagi siswa dalam meningkatkan pemahaman konsep matematikanya. Menurut Fahmi, Syariful, \& Marsigit (2014), sajian audio visual atau lebih dikenal dengan multimedia dapat dimanfaatkan untuk mengkonkritkan sesuatu yang abstrak. Macromedia flash lebih menarik perhatian siswa dengan penyajiannya secara komunikatif berupa gambar, animasi dan video (Gustina, Nur Abu, \& Hamsyah, 2016). Pada penelitian ini, siswa dapat gambaran tentang terbentuknya sebuah persamaan dari setiap bangun ruang, misalnya animasi luas permukaan bola.

Berdasarkan latarbelakang, tujuan penelitian ini adalah untuk meningkatkan kemampuan pemahaman konsep matematika siswa dengan menggunakan macromedia flash, dan mendeskripsikan respons siswa yang pembelajarannya menggunakan macromedia flash.

\section{Metode}

Jenis penelitian yang digunakan adalah metode Quasi Experimental Design. Hal ini karena tidak dapat sepenuhnya mengontrol faktor-faktor eksternal 
yang mempengaruhi pemahaman konsep matematika siswa (Sugiyono, 2016). Penelitian ini menggunakan desain eksperimen One Group Pretes Posttest Design, dengan satu kelompok sampel menggunakan Macromedia flash pada pembelajarannya Desain penelitan dapat digambarkan pada Tabel 1 .

Tabel 1. Rancangan Penelitian

\begin{tabular}{crcc}
\hline Kelompok & Pre-test & Perlakuan & Post-test \\
\hline Eksperimen & $\mathrm{O}_{1}$ & $X$ & $\mathrm{O}_{2}$ \\
\hline
\end{tabular}

Pada Tabel 1, X merupakan pembelajaran dengan macromedia flash dengan menggunakan pre-test dan post-test. Penelitian ini untuk membandingkan peningkatan pemahaman matematis siswa sebelum dan sesudah pembelajaran.

Populasi dalam penelitan ini adalah siswa kelas IX SMPN 3 Majalengka tahun ajaran 2018/2019 sebanyak 348 siswa. Teknik pengambilan sampel yang digunakan adalah purposive sampling menetapkan satu kelas sebanyak 36 siswa sebagai sampel penelitian. Pertimbangannya adalah sampel tersebut memiliki kriteria yang harus dipenuhi dalam penelitian ini. Sekolah ini merupakan sekolah percontohan penyelenggaraan K-13 di kabupaten Majalengka. Lokasi berada di tengah kota dan merupakan sekolah yang memiliki akreditasi A (kemendikbud, 2019).

Instrumen penelitian ini adalah soal uraian pre-test dan post-test untuk mengukur kemampuan pemahaman konsep matematika pada pokok bahasan Bangun Ruang Sisi Lengkung. Indikator pemahaman konsep matematika yang diukur dalam penelitian ini tersaji pada Tabel 2.

Tabel 2. Indikator Pemahaman Konsep Matematika

\begin{tabular}{|c|c|c|}
\hline \multicolumn{2}{|c|}{ Indikator Pemahaman Matematis } & \multirow{2}{*}{ Indikator Pencapaian } \\
\hline Skemp & Polya & \\
\hline \multirow{4}{*}{$\begin{array}{l}\text { Pemahaman } \\
\text { Instrumental }\end{array}$} & Mekanikal & Siswa dapat menghitung luas permukaan tabung \\
\hline & & Siswa dapat menentukan luas permukaan bola \\
\hline & Induktif & yang baru jika jari-jarinya ditambah \\
\hline & Rasional & $\begin{array}{l}\text { Siswa dapat menentukan volume kerucut jika } \\
\text { sebagiannya telah terisi }\end{array}$ \\
\hline Pemahaman & & Siswa dapat menghitung debit air yang tumpah \\
\hline Relasional & Intuitif & dari sebuah tabung jika dimasukkan sebuah bola \\
\hline
\end{tabular}


Sebelum dipergunakan, perangkat soal dilakukan expert judgement dan estimasi reliabilitas menggunakan Alpha Cronbach (Arikunto, 2013). Hasil validasi oleh ahli menunjukkan bahwa untuk tes kemampuan pemahaman konsep matematika, keempat butir soal valid. Hasil estimasi reliabilitas dengan Alpha Cronbach menunjukkan bahwa untuk tes kemampuan pemahaman konsep matematika berada pada kategori baik.

Sementara itu, instrumen non tes berupa angket untuk mengetahui respons siswa terhadap penggunaan macromedia flash dalam pembelajaran matematika. Indikator respons siswa yang diukur dalam penelitian ini tersaji pada Tabel 3.

Tabel 3. Indikator Respons Siswa

\begin{tabular}{cl}
\hline Aspek & \multicolumn{1}{c}{ Indikator } \\
\hline \multirow{2}{*}{ Menarik } & $\begin{array}{l}\text { Alat peraga ini dibuat menarik dengan memperhatikan warna, } \\
\text { kontur permukaan yang lembut, dan beratnya, sehingga siswa } \\
\text { tertarik untuk menyentuh, meraba, dan memegangnya. }\end{array}$ \\
Alat peraga bergradasi ini memungkinkan digunakan dengan \\
Bergradasi & $\begin{array}{l}\text { melibatkan panca indra anak dan bisa digunakan untuk siswa } \\
\text { dalam hal pembentukan konsep belajar anak. } \\
\text { Alat peraga yang dibuat memiliki pengendali kesalahan sehingga } \\
\text { Auto-correction } \\
\text { siswa akan mengetahui jika mereka melakukan kesalahan saat } \\
\text { menggunakan alat peraga tersebut. } \\
\text { Alat peraga yang digunakan dapat mengembangkan } \\
\text { kemampuan siswa untuk belajar secara mandiri. } \\
\text { Kontekstual yang dimaksud adalah sesuai dengan lingkungan } \\
\text { yang ada di sekitar siswa }\end{array}$ \\
\hline
\end{tabular}

Angket menggunakan skala Likert dengan lima pilihan jawaban yaitu Sangat Setuju (SS), Setuju (S), Cukup (C), Tidak Setuju (TS), dan Sangat Tidak Setuju (STS). Angket terdiri dari 20 butir pernyataan yang mengacu pada indikator respons siswa terhadap macromedia flash dalam pembelajaran. Angket respons siswa diujicobakan pada kelas lain untuk mengetahui tingkat keterbacaan bahasa. Berdasarkan hasil ujicoba diperoleh gambaran bahwa semua pernyataan dapat dipahami dengan baik oleh siswa.

Teknik analisis data dilakukan dengan membandingkan hasil tes sebelum dan sesudah pembelajaran dengan macromedia flash. Peningkatan kemampuan konsep matematika siswa dilakukan melalui analisis deskriptif dan analisis inferensial. Analiasis deskriptif memberikan perbandingan singkat dari hasil pre-test dan post-test yang dikaitkan dengan kemampuan pemahaman konsep matematika siswa. Analisis inferensial dilakukan melalui Paired t-test untuk melihat peningkatan kemampuan pemahaman 
konsep matematika siswa. Selain itu, peningkatan kemampuan konsep matematika siswa terlihat dari gain hasil pre-test dan post-test

Data angket dianalisis yang bertujuan untuk menggambarkan respons siswa terhadap penggunaan macromedia flash dalam pembelajaran matematika dengan menggunakan persamaan: $p=\frac{f}{n} x 100 \%$, dengan kategori interpretasi pada Tabel 4 (Sugiyono, 2016).

Tabel 4. Kategori Respons Siswa

\begin{tabular}{ll}
\hline Skala & Kategori \\
\hline $1,00-1,80$ & Sangat Tidak Baik \\
$1,81-2,60$ & Tidak Baik \\
$2,62-3,40$ & Cukup Baik \\
$3,42-4,20$ & Baik \\
$4,21-5,00$ & Sangat Baik \\
\hline
\end{tabular}

\section{Hasil dan Pembahasan}

Berdasarkan tes pemahaman konsep matematika tentang Bangun Ruang Sisi Lingkung di kelas eksperimen, hasilnya menunjukkan bahwa siswa mengalami peningkatan setelah pembelajarannya menggunakan macromedia flash. Ini bisa terlihat dari rata-rata skor dengan memperhatikan standar deviasi pada Tabel 5 .

Tabel 5. Pemahaman Konsep Matematika Siswa

\begin{tabular}{ccccccc}
\hline $\begin{array}{c}\text { Pemahaman } \\
\text { Konsep } \\
\text { Matematika }\end{array}$ & Mean & Variance & Std. Deviation & Min & Max & $\begin{array}{c}\text { Skor } \\
\text { Ideal }\end{array}$ \\
\hline Pre-test & 4.94 & 3.940 & 1.98 & 2 & 8 & 20 \\
Post-test & 15.31 & 5.30 & 2.30 & 11 & 19 & 10 \\
\hline
\end{tabular}

Berdasarkan Tabel 5, terlihat bahwa pre-test memiliki rata-rata kelas yang jauh dari ideal, dengan standar deviasi yang sangat kecil. Artinya sebaran kemampuan siswa hampir berada pada satu titik yang sama. Hal ini menjelaskan bahwa kemampuan siswa sangat seragam dengan sebaran yang sangat sempit.

Sementara itu, pada post-test nilai tertinggi hampir mencapai skor maksimal. Rata-rata kelas yang meningkat juga menjadi indikator meningkatnya pemahaman konsep siswa tentang materi yang diberikan. Selain itu, pada skor post-test standar deviasi semakin melebar, artinya sebaran kemamuan siswa semakin beragam. 
Tabel 6. Peningkatan Kemampuan Pemahaman Konsep

\begin{tabular}{|c|c|c|c|}
\hline \multicolumn{2}{|c|}{ Indikator Pemahaman Matematis } & \multirow{2}{*}{ Gain } & \multirow{2}{*}{ Kategori } \\
\hline Skemp & Polya & & \\
\hline \multirow{3}{*}{ Pemahaman Instrumental } & Mekanikal & 0.76 & Tinggi \\
\hline & Induktif & 0.75 & Tinggi \\
\hline & Rasional & 0.68 & Sedang \\
\hline Pemahaman Relasional & Intuitif & 0.57 & Sedang \\
\hline
\end{tabular}

Berdasarkan Tabel 6, terlihat bahwa setiap indikator pemahaman berada pada kategori tinggi dan sedang, baik itu berdasarkan Skemp maupun Polya. Artinya kemampuan pemahaman siswa mengalami peningkatan untuk setiap indikatornya.

Tabel 7. Respons Siswa terhadap Penggunaan Macromedia flash

\begin{tabular}{|c|c|c|c|c|c|c|c|}
\hline \multirow{2}{*}{ Aspek } & \multirow{2}{*}{ Indikator } & \multicolumn{5}{|c|}{ Respons Siswa (\%) } & \multirow{2}{*}{$\bar{X}$} \\
\hline & & SS & $S$ & $\mathrm{C}$ & TS & STS & \\
\hline Menarik & $\begin{array}{l}\text { Alat peraga ini dibuat menarik } \\
\text { dengan memperhatikan } \\
\text { warna, kontur permukaan } \\
\text { yang lembut, dan beratnya, } \\
\text { sehingga siswa tertarik untuk } \\
\text { menyentuh, meraba, dan } \\
\text { memegangnya. }\end{array}$ & 15.28 & 39.58 & 22.22 & 20.83 & 2.08 & 1.69 \\
\hline Bergradasi & $\begin{array}{c}\text { Alat peraga bergradasi ini } \\
\text { memungkinkan digunakan } \\
\text { dengan melibatkan panca } \\
\text { indra anak dan bisa digunakan } \\
\text { untuk siswa dalam hal } \\
\text { pembentukan konsep belajar } \\
\text { anak. }\end{array}$ & 7.54 & 30.95 & 33.33 & 21.83 & 6.35 & 7.81 \\
\hline $\begin{array}{c}\text { Auto- } \\
\text { correction }\end{array}$ & $\begin{array}{c}\text { Alat peraga yang dibuat } \\
\text { memiliki pengendali } \\
\text { kesalahan sehingga siswa akan } \\
\text { mengetahui jika mereka } \\
\text { melakukan kesalahan saat } \\
\text { menggunakan alat peraga } \\
\text { tersebut. }\end{array}$ & 4.17 & 37.50 & 27.78 & 29.17 & 1.39 & 5.00 \\
\hline $\begin{array}{c}\text { Auto- } \\
\text { education }\end{array}$ & $\begin{array}{c}\text { Alat peraga yang digunakan } \\
\text { dapat mengembangkan } \\
\text { kemampuan siswa untuk } \\
\text { belajar secara mandiri. }\end{array}$ & 6.94 & 52.08 & 12.50 & 26.39 & 2.08 & 4.72 \\
\hline Kontekstual. & $\begin{array}{c}\text { Kontekstual yang dimaksud } \\
\text { adalah sesuai dengan } \\
\text { lingkungan yang ada di } \\
\text { sekitar siswa }\end{array}$ & 6.48 & 40.74 & 24.07 & 24.07 & 4.63 & 0.78 \\
\hline
\end{tabular}


Berdasarkan Tabel 7, terlihat bahwa rata-rata respons siswa adalah setuju untuk setiap indikator. Hal ini menunjukkan bahwa siswa memberikan respons yang baik dalam penggunaan macromedia flash dalam pembelajaran. Namun data pada Tabel 7 tidak memberikan informasi cukup untuk menyimpulkan yang mempengaruhi pemahaman konsep matematika siswa. Oleh karena itu, Paired t-test diperlukan untuk mendapatkan informasi lebih mendalam.

Berdasarkan hasil uji normalitas pada penelitian ini, untuk menjawab rumusan masalah digunakan uji-t yang sebelumnya dilakukan uji prasyarat. Adapun uji prasyat adalah data berdistribusi normal dan homogen. Hasil dari pengujian prasyarat dapat dilihat pada Tabel 8 dan Tabel 9.

Tabel 8. Uji Normalitas Kemampuan Pemahaman Matematis Siswa

\begin{tabular}{cccccc}
\hline Uji Normalitas & \multicolumn{5}{c}{ Shapiro-Wilk } \\
\hline Skor Pemahaman Matematis & Kelas & Statistic & Statistic & df & Sig. \\
& Pretes & .142 & .920 & 36 & .013 \\
& Postes & .130 & .951 & 36 & .111 \\
\hline
\end{tabular}

Tabel 8 menunjukan bahwa data pre-test dan post-test berdistribusi normal. Simpulan ini diperoleh setelah melihat kedua data memiliki p-value lebih dari 0,05. Artinya pengujian dapat dilanjutkan untuk mengetahui perbedaan varians data.

Tabel 9. Uji Homogenitas Kemampuan Pemahaman Matematis Siswa

\begin{tabular}{cccccc}
\hline & Test of Homogeneity of Variance & & & \\
& & $\begin{array}{c}\text { Levene } \\
\text { Statistic }\end{array}$ & df1 & df2 & Sig. \\
\hline \multirow{3}{*}{$\begin{array}{c}\text { Skor Pemahaman } \\
\text { Matematis }\end{array}$} & Based on Mean & .827 & 1 & 70 & .366 \\
& Based on Median and with & .849 & 1 & 70 & .360 \\
& Based on trimmed mean & .823 & 1 & 70 & .367 \\
\hline
\end{tabular}

Tabel 9 menunjukan bahwa hasil uji kehomogenan data pre-test dan post-test menghasilkan simpulan bahwa data homogen. Simpulan ini diperoleh setelah melihat kedua data memiliki p-value lebih dari 0,05. Setelah melakukan uji asumsi diperoleh alat uji statistika inferensial adalah uji perbedaan rata-rata paired t-test.

Tabel 10. Uji-t Kemampuan Pemahaman Matematis Siswa

\begin{tabular}{ccccc}
\hline & $N$ & Correlation & Sig. \\
\hline Pair 1 & $\begin{array}{c}\text { Pretes } \mathcal{E} \\
\text { Postes }\end{array}$ & 36 & .679 & .000 \\
& & & \\
\hline
\end{tabular}


Tabel 10 menunjukan bahwa hasil paired t-test, p-value kurang dari 0,05 yang menunjukkan bahwa dua rerata yang berbeda. Hal ini menunjukkan terdapat perbedaan kemampuan pemahaman konsep matematika siswa sebelum dan sesudah pembelajaran menggunakan macromedia flash. Hal ini juga diperkuat nilai korelasi antara hasil pre-test dengan post-test sebesar 0,679 , artinya hubungan kuat dan positif.

Penggunaan aplikasi macromedia flash dalam pembelajaran matematika merupakan sesuatu yang belum lumrah dilakukan oleh guru maupun siswa SMP di Majalengka. Selain karena fasilitas yang masih terbatas, juga karena keterbatasan guru dalam pemanfaatan ICT. Pembelajaran berbasis ICT

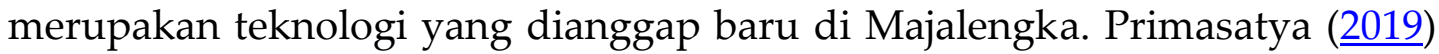
menyatakan bahwa untuk menjadi seorang pendidik (guru) harus hati-hati dan jeli dalam memilih menggunakan media pembelajaran. Anggraeni, Andriani, \& Yahya (2019) menyebutkan bahwa matematika memiliki peran yang sangat penting bagi sains dan teknologi, tetapi sering dianggap pelajaran yang sangat sulit dan bahkan menjadi hal yang menakutkan dalam setiap kegiatan belajar mengajar.

Penggunaan aplikasi macromedia flash merupakan satu langkah yang tepat dalam memaksimalkan penggunaan teknologi dalam pembelajaran matematika. Seiring dengan pesatnya perkembangan ilmu pengetahuan dan teknologi juga dituntut untuk meningkatkan kualitas pendidikan sebagai kompensasi, sehingga akan menghasilkan sumber daya manusia (SDM) yang berkualitas dan siap bersaing dengan bangsa lain. Yuliarni, Marzal, \& Kuntarto (2019) membuat multimedia komposisi alur cerita atau storyboard yang memberi gambaran tentang materi pengajaran apa yang akan disampaikan.

Macromedia flash dapat membantu menjelaskan konsep matematika yang kepada siswa dengan tampilan yang menarik. Macromedia flash dalam pembelajaran matematika dapat mensimulasikan suatu konsep matematika secara nyata. Macromedia flash merupakan perangkat lunak (software) yang dimanfaatkan pengembangannya disebut juga metode simulasi yang dapat membantu pembelajaran. Liberna \& Nusantari (2018) menggunakan macromedia flash, siswa dapat langsung melihat simulasi dan demonstrasi yang menyerupai peristiwa aktual, sehingga siswa dapat menangkap konsep dengan baik dan benar dan dapat diterapkan dalam kehidupan sehari-hari. 


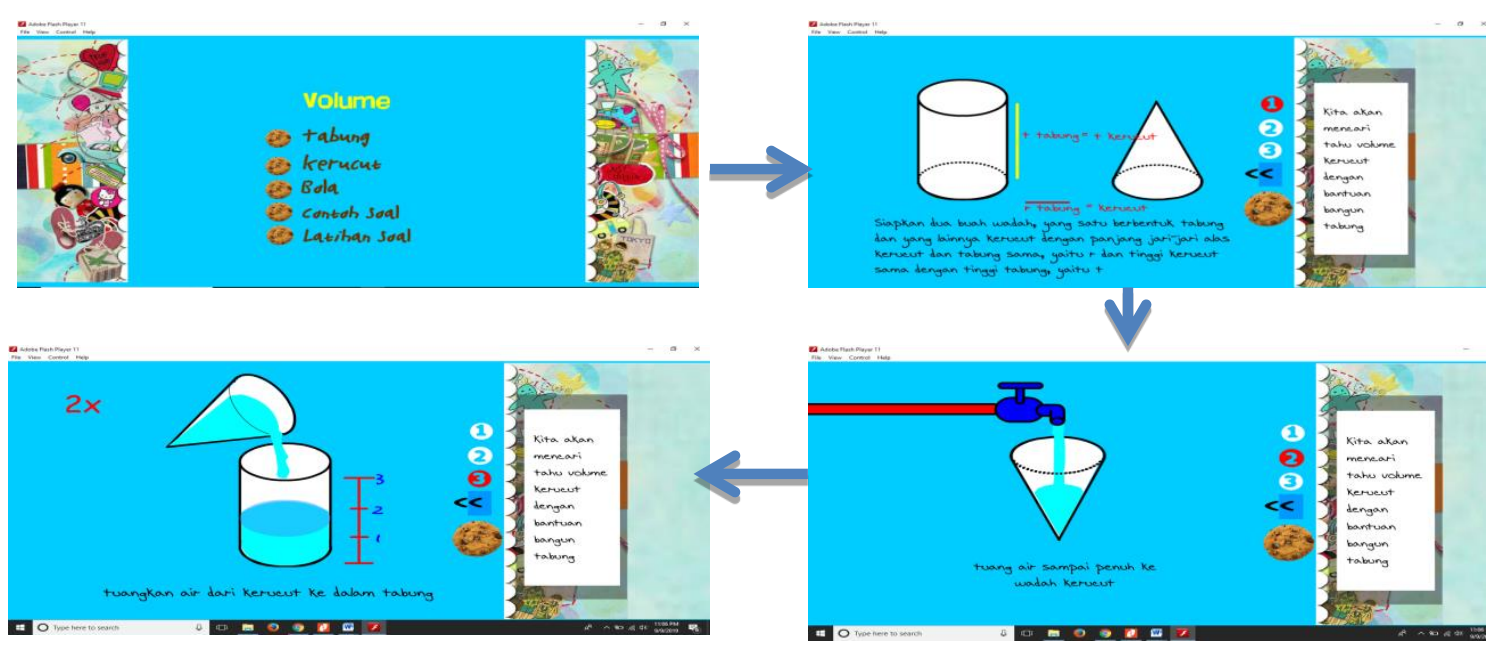

Gambar 1. Ilustrasi Mencari Volume Kerucut

Gambar 1 menampilkan hasil Macromedia flash pada penelitian ini terkait animasi konsep bangun ruang sisi lengkung, diantaranya: jaring-jaring, luas permukaan voume dan latihan soal dari tabung, kerucut, bola dan soal-soal latihan.

Pada pembelajaran siswa mendapatkan visualisasi yang menarik tentang konsep bangun ruang sisi lengkung. Siswa memahami volume kerucut $\frac{1}{3}$ volume tabung dari sebuah animasi, dan memberikan keleluasaan untuk memahami konsep matematika dengan bahasanya sendiri. Dimana sebelumnya siswa telah memahami volume tabung $=\pi r^{2} t$, Sehingga volume kerucut adalah $\frac{1}{3}$ volume tabung $=\frac{1}{3} \pi r^{2} t$. Persamaan ini siswa temukan melalui peragaan yang sangat menarik dan menyenangkan. Marnita \& Ernawati (2017) proses pembelajaran menggunakan Macromedia flash dan multimedia ditambah dengan penerapan praktikum sederhana, akan membuat siswa dapat menemukan konsep yang lebih baik, dan akan dapat menggeneralisasi temuan apa pun menjadi contoh di sekitarnya.

Hasil penelitian menunjukkan bahwa kemampuan pemahaman matematis siswa sebelum dan sesudah penggunaan macromedia flash dalam pembelajaran meningkat secara signifikan. Rata-rata peningkatan pemahaman konsep matematika siswa adalah 0.69 dengan kategori sedang. Artinya, penggunaan macromedia flash dapat meningkatkan kemampuan pemahaman konsep siswa berdasarkan Skemp maupun Polya seperti yang tersaji pada Gambar 2 dan Gambar 3. Hal ini sejalan dengan hasil penelitian Octamela, Suweken, \& Ardana (2019) yang menunjukan bahwa kemampuan pemahaman matematis pada materi geometri dapat meningkat melalui 
penggunaan pembelajaran berbantuan teknologi. Yuliarni, Marzal \& Kuntarto (2019) menyatakan bahwa multimedia yang dibuat dengan mempertimbangkan prinsip-prinsip pembelajaran akan dapat mengajar dengan lebih baik. Nasution, Sinaga, \& Mukhtar (2019) mengemukakan media pembelajaran yang dikembangkan dengan menggunakan Macromedia flash dapat meningkatkan pemahaman konseptual siswa dan pembelajaran yang diatur sendiri.

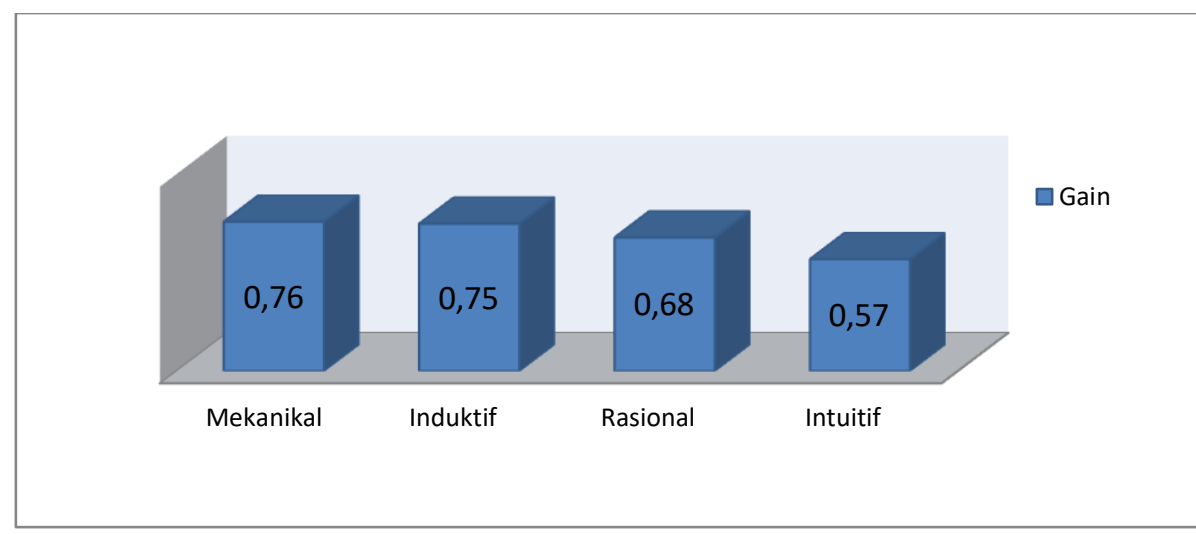

Gambar 2. Peningkatan Pemahaman Konsep Matematika berdasarkan Indikator Polya

Gambar 2 memperlihatkan bahwa pemahaman mekanikal siswa memiliki peningkatan yang lebih tinggi daripada yang lain. Artinya siswa dalam menguasi konsep-konsep matematika akan lebih baik menggunakan macromedia flash.

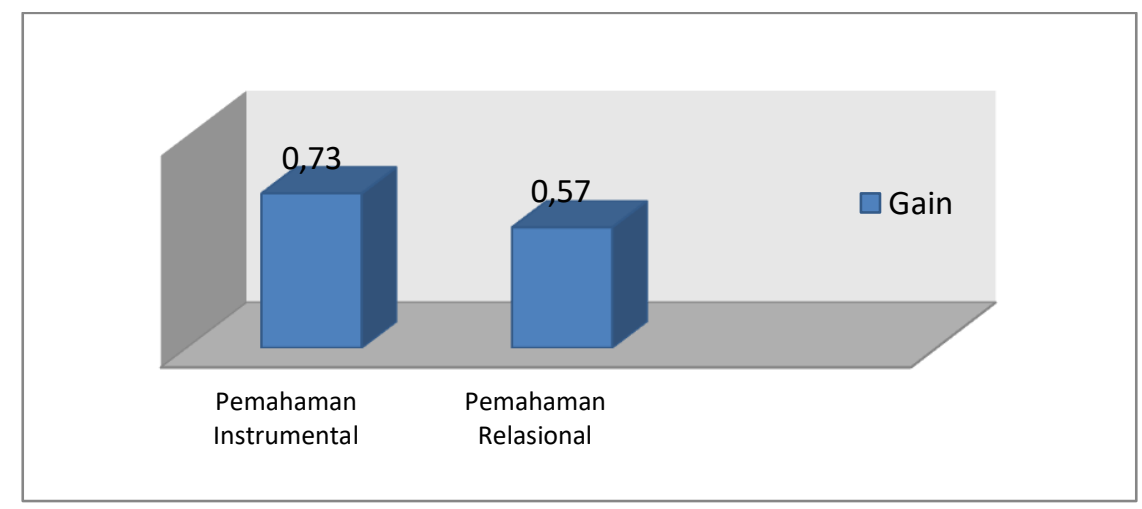

Gambar 3. Peningkatan Pemahaman Konsep Matematika berdasarkan Indikator Skemp

Gambar 3 menunjukan bahwa peningkatan pemahaman instrumental siswa lebih baik dari pemahaman relasional. Artinya mendukung hasil pada pemahaman mekanikal bahwa penguasaan konsep matematika siswa meningkat lebih baik dari pemahaman yang lain. 
Hasil ini juga didukung oleh hasil angket respons siswa terhadap pembelajaran menggunakan macromedia flash. Siswa cenderung memilih jawaban setuju untuk pernyataan positif dan tidak setuju untuk pernyataan yang bersifat negatif.

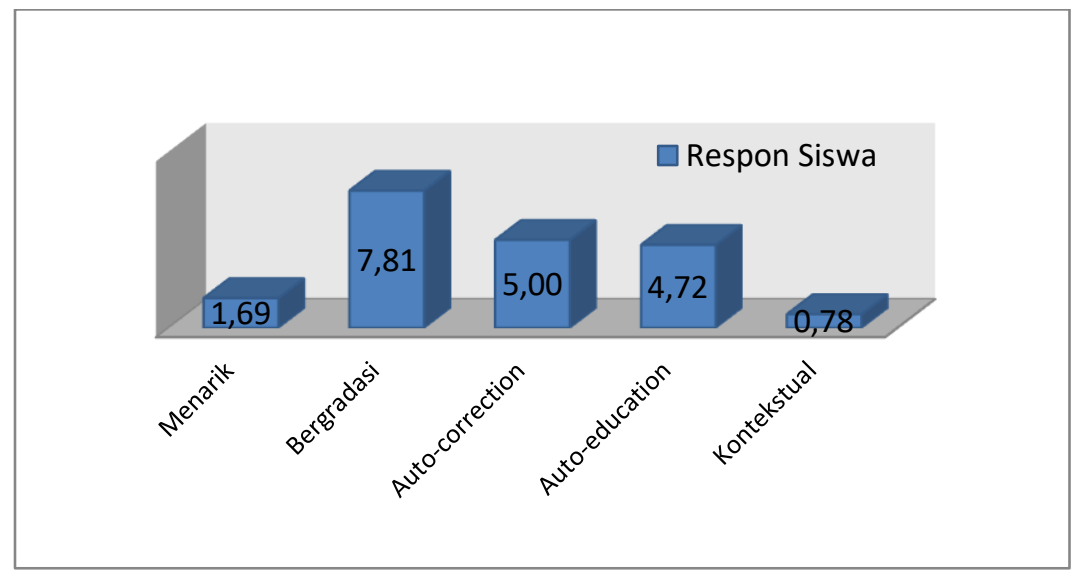

Gambar 4. Respons Siswa terhadap Penggunaan Macromedia flash

Gambar 4 memperlihatkan bahwa respons siswa setiap indikator menunjukkan respons positif dengan rata-rata skor respons siswa sebesar 4.00. Rata-rata ini di atas skor netralnya sebesar 2,5. Artinya siswa memiliki respons positif terhadap pembelajaran dengan menggunakan macromedia flash dalam pembelajaran.

\section{Simpulan}

Berdasarkan hasil kajian dan analisis data, maka dapat disimpulkan bahwa penggunaan macromedia flash dalam pembelajaran matematika berpengaruh terhadap signifikan terhadap kemampuan pemahaman konsep matematika siswa SMP. Rata-rata peningkatan kemampuan pemahaman konsep matematika berada pada kategori sedang. Selain itu, siswa juga memiliki respons positif terhadap penggunaan macromedia flash dalam pembelajaran matematika. Namun demikian, peneliti menemukan beberapa fakta di lapangan, diantaranya, (1) pada awal pembelajaran, siswa ragu-ragu untuk mengulang kembali pemahamannya tentang konsep Bangun Ruang Sisi Lengkung dengan bahasanya sendiri. Hal ini terjadi karena selama ini, siswa hanya mendengarkan dan mencatat materi yang disampaikan guru; (2) siswa tidak terbiasa mengoperasikan komputer dalam pembelajaran. Indikatornya siswa kikuk dan takut salah langkah dalam mengoperasikan komputer; (3) guru masih belum mengoptimalkan penggunakan software dalam pembelajaran matematika. Rekomendasi untuk guru adalah mulai memanfaatkan dan mengoptimalkan penggunakan teknologi dalam pembelajaran matematika. 


\section{Ucapan Terima Kasih}

Ucapan terimakasih kepada DRPM Kemenristek Dikti yang telah membiayai penelitian ini.

\section{Daftar Pustaka}

Abidin, Z., Mulyono, T., \& Saputro, E. (2013). Upaya Meningkatkan Motivasi dan Pemahaman Siswa pada Materi Geometri dan Pengukuran di SMP 33 Semarang. Kreano: Jurnal Matematika Kreatif-Inovatif, 2(2), 133-141.

Anggraeni, R., Andriani, S., \& Yahya, AD. (2019). Effect of Thinking Aloud Pair Problem Solving (TAPPS) Method with Audio Visual Media for Students' Critical Thinking Ability. International Journal of Trends in Mathematics Education Research 2(1). 31-33.

Arikunto, S. (2013). Prosedur Penelitian: Suatu Pendekatan Praktik. Jakarta: Rineka Cipta.

Costley, K. C. (2014). The Positive Effects of Technology on Teaching and Student Learning. Arkansas Tech University.

Fahmi, Syariful \& Marsigit, M. (2014). Pengembangan Multimedia Macromedia flash dengan Pendekatan Kontekstual dan Keefektifannya terhadap Sikap Siswa pada Matematika Developing Multimedia Macromedia flash with Contextual Approach and Its Effect on Students' Attitude toward Mathematics. PYTHAGORAS: Jurnal Pendidikan Matematika, 9(1), 90-98.

Gustina, Nur Abu, S. H., \& Hamsyah, E. F. (2016). Pengaruh Penggunaan Media Pembelajaran Berbasis Macromedia flash 8 Terhadap Motivasi dan Hasil Belajar Kognitif Siswa Kelas VII SMPN 18 Makassar Studi pada Materi Pokok Asam , Basa dan Garam Influence of Media-Based Learning Macromedia flash 8 Motivation. Chemica, 17(2), 12 18.

Herbst, P., Chieu, V. M., \& Rougee, A. (2014). Approximating the Practice of Mathematics Teaching: What Learning Can Web-based, Multimedia Storyboarding Software Enable?. Contemporary Issues in Technology and Teacher Education, 14(4), 356-383.

Istikomah, E. (2019). The Relationship Between Conceptual Understanding and Student Learning Outcomes Through The Use of Geometers Sketchpad Software. Journal of Physics: Conference Series, 1157(4), 042070.

Kemendikbud. (2019). Hasil Ujian Nasional. Jakarta: Kemendikbud.

Kent, G., \& Foster, C. (2016). Re-conceptualising conceptual understanding in mathematics. CERME 9-Ninth Congress of the European Society for Research in Mathematics Education, 2656-2661.

Liberna, H., \& Nusantari, D. O. (2018). The Influence of Macromedia flash Learning on the Students' Mathematic Concept Understanding. Journal of Mathematics Education, 3(1), 16.

Adamides, M. H., \& Nicolaou, N. (2004). Technology in Mathematics. Science Education International, 15(2), 139-151.

Marnita \& Ernawati. (2017). The Use of Interactive Multimedia (Macromedia flash) to Increase Creative Thinking Ability of Students in Basic Physics Subject. Jurnal Pendidikan Fisika, 13(2), 71-78.

Moradmand, N., Datta, A., \& Oakley, G. (2014, June). An Interactive Multimedia Development Life Cycle Model Based on a Cognitive Theory of Multimedia Learning. In EdMedia+ Innovate Learning ( $p p$. 746-761). Association for the Advancement of Computing in Education (AACE).

Nasution, N., Sinaga, B., \& Mukhtar, M. (2019). Developing Learning Media Assisted-flash 
Macromedia Software by Applying Discovery Model to Improve Students' Concept and Self Regulated Learning on Senior High School. American Journal of Educational Research, 7(2), 161-165.

Ningsih, P. R. (2013). Penerapan Metode Realistic Mathematics Education (RME) Pada Pokok Bahasan Perbandingan Senilai dan Berbalik Nilai Di Kelas VII E SMP IPIEMS Surabaya. Gamatika, III(2), 177-184.

Ningsih, Y. L., \& Paradesa, R. (2018). Improving students' understanding of mathematical concept using maple. Journal of Physics: Conference Series, 948(1), 012034.

Octamela, K. S., Suweken, G., \& Ardana, I. M. (2019). Pemahaman Matematis Siswa Dengan Menggunakan Buku Elektronik Interaktif Berbantuan Geogebra. JNPM (Jurnal Nasional Pendidikan Matematika), 3(2), 305-315.

Polya, G. (1973). How To Solve It Mathematical Method. New Jersey: Princeton Univeversity Press. (2nd ed.). Princeton.

Primasatya, N., \& Jatmiko, J. (2019). Implementation of Geometry Multimedia Based on Van Hiele's Thinking Theory for Enhancing Critical Thinking Ability for Grade V Students. International Journal of Trends in Mathematics Education Research, 1(2).

Setyaningrum, W. (2018). Blended Learning: Does it help students in understanding mathematical concepts? Jurnal Riset Pendidikan Matematika, 5(2), 244-253.

Skemp, R., \& Prologue, T. (2005). Relational and Instrumental Understanding. 1-15.

Sugiyono. (2016). Metode Penelitian Kuantitatif, Kualitatif dan R\&D. Bandung: PT Alfabet.

Yuliarni, I., Marzal, J., \& Kuntarto, E. (2019). Analysis of Multimedia Learning Mathematics Storyboard Design. International Journal of Trends in Mathematics Education Research, 2(3), 149-152. 